\title{
Pengaruh Konsentrasi Ragi Dan Lama Fermentasi Terhadap Kadar Air, Glukosadan Organoleptik Pada Tape Singkong
}

\author{
Sahratullah $^{1}$, Dwi Soelistya Dyah Jekti ${ }^{2}$, Lalu Zulkifli ${ }^{2}$ \\ ${ }^{1}$ Mahasiswa Program Studi Magister Pendidikan IPA Program Pasca Sarjana UniversitasMataram \\ ${ }^{2}$ Dosen Program Studi Magister Pendidikan IPA Program Pasca Sarjana Universitas Mataram \\ email: bioenamsahratullah@yahoo.co.id
}

\begin{abstract}
Abstrak
Tujuan dari penelitian ini adalah mengetahuipengaruh (1) konsentrasi ragi, (2) lama fermentasi serta (3) interaksi antara konsentrasi ragi dan lama fermentasi terhadap kadar air, glukosa dan organoleptik pada tape singkong. Penelitian dilakukan di Laboratorium Kimia Analitik Universitas Mataram dan Fakultas Keguruan dan Ilmu Pendidikan Universitas Mataram. Bahan yang digunakan dalam penelitian adalah tape singkong. Penelitian dilaksanakan secara eksperimental berdasarkan RAL pola faktorial. Faktor I konsentrasi ragi $(0,5 ; 1$ dan 1,5\%) dan faktor II lama fermentasi (1, 2 dan 3 hari) dengan 3 kali ulangan. Parameter penelitian meliputi kadar air, glukosa dan organoleptik. Hasil penelitian menunjukkan bahwa(1)Konsentrasi ragiberpengaruh terhadap kadar $\operatorname{air}(\mathrm{p} \leq 0,05)$ dan organoleptik $(\mathrm{p}<0,05)$ tetapi tidak berpengaruh ( $>0$,05)pada kadar glukosatape singkong.(2) Lama fermentasiberpengaruh terhadap kadar air ( $<<$ $0,05)$, kadar glukosa $(\mathrm{p}<0,05)$ dan organoleptik $(\mathrm{p}<0,05)$ tape singkong.(3) Interaksi antara konsentrasi ragi dan lama fermentasi berpengaruh $(\mathrm{p}<0,05)$ terhadap kadar air tetapi tidak berpengaruh terhadap kadar glukosa $(p>0,05)$ dan organoleptik $(p>0,05)$ tape singkong.
\end{abstract}

Kata kunci: konsentrasi ragi, lama fermentasi, kadar air, kadar glukosa, organoleptik,

\begin{abstract}
The purpose of this research arethe influence of (1) concentration of yeast, (2) long fermentingas well as (3) interaction between concentration of yeast and long fermentingagainst the levels of water, glucose and organoleptik on fermented cassava. Research was conducted in Laboratory ChemistryAnalytic of Mataram University and Faculty of Education of Mataram University. Material used in this research are fermented cassava. Thisresearch is experimentresearch with Random Complete Design factorial pattern. Factor I concentration of yeast $(0,5 ; 1$ and $1,5 \%)$ factor II long fermenting(1, 2 and 3day) with 3 repetition. Parameters research covering the levels of water, glucose and organoleptik. The results of this research are (1) Concentration of yeastinfluential on the levels of water $(p \leq 0,05)$ and organoleptik $(p<0,05)$ but not influential ( $p>0,05)$ on glucose level of fermented cassava. (2) Long fermentinginfluential on the levels of water $(p<0,05)$, glucose $(p<0,05)$ and organoleptik $(p<0,05)$ of fermentedcassava. (3) Interaction between concentration of yeast and long fermenting influential on waterlevel $(\mathrm{p}<0,05)$ but not influential on the levels ofglucose $(p>0,05)$ and organoleptik $(p>0,05)$ of fermented cassava.
\end{abstract}

Keyword: yeast concentration, fermentations time, levels of water, levels of glucose, organoleptik 


\section{PENDAhuluan}

Ketersediaan bahan pangan singkong (Manihot esculenta) di NTB cukup banyak, yang dibuktikan dengan posisi Indonesia sebagai Negara penghasil singkong terbesar ketiga setelah Brazil dan Thailand (Hidayati et $a l, 2013)$. Hal ini sesuai dengan hasil survei ekonomi OECD Indonesia tahun 2015 yang menunjukkan peningkatan produksi singkong dari tahun 2000 (FAOSTAT, 2015). Data BPS Provinsi NTB menunjukkan bahwa produksi singkong pada tahun 2015 di NTB adalah 107.254 ton (Badan Pusat Statistik Provinsi NTB, 2016). Menurut Menteri Pertanian Republik Indonesia, salah satu kegiatan utama dari diversifikasi konsumsi pangan adalah promosi dan sosialisasi pola konsumsi pangan beragam, serta pengembangan olahan pangan berbasis pangan lokal (Badan Ketahanan Pangan Kementrian Pertanian RI, 2012).

Singkong (M. esculenta) merupakan tanaman yang kandungan karbohidrat serta energi cukup tinggi (Wardany, 2012). Menurut Departemen Pertanian (2012), zat gizi yang terkandung dalam bahan makanan, khususnya kandungan kadar air dan karbohidrat pada singkong sebesar 60,00 gram dan 37,90 gram per 100 gram bahan.

Sebagaimana telah diuraikan di atas bahwa di wilayah NTB ketersediaan bahan pangan seperti singkong cukup banyak. Diversifikasi pangan dianjurkan oleh pemerintah untukmembuat variasi makanan melalui proses fermentasi. Selain itu dapat mencegah terjadinya kerusakan pada bahan pangan pasca panen. Kerusakan pada bahan pangan pasca panen dapat diatasi dengan membuat variasi makanan melalui proses fermentasi yaitu tape (Badan Ketahanan Pangan Kementrian Pertanian RI, 2012). Kualitas produk fermentasi dipengaruhi oleh suhu, kelembaban, $\mathrm{pH}$, nutrisi, jumlah ragi serta lama waktu yang digunakan. Beberapa penelitian telah dilakukan untuk melihat kadar glukosa tertinggi untuk fermentasi gaplek ketela pohon varietas mukibat pada lama fermentasi 10 hari dan dosis ragi $4 \%$ mencapai 51,14\% (Asngad dan Suparti, 2009). Hasil penelitian dari Badan Ketahanan Pangan Daerah Provinsi Jawa Barat (2014), menunjukkan bahwa kadar air dan kadar glukosa pada tape ketan sebesar 56,10 gram dan 42,50 gram dari 100 gram bahan. Serta penelitian Hasanah (2007), menyatakan bahwa merek ragi tidak berpengaruh nyata terhadap hasil fermentasi beras ketan putih.

Tape yang dijual di pasar tradisional serta tape yang dijadikan sebagai bahan campuran dalam makanan dan minuman biasanya terlalu berair, kurang manis dan terasa asam. Hal tersebut diperkirakan karena terlalu banyaknya jumlah ragi yang diberikan serta waktu fermentasi yang terlalu lama. Penelitian yang dilakukan ini bertujuan untuk melihat pengaruh konsentrasi ragi dan lama fermentasi terhadap kadar air, glukosa dan organoleptik pada tape singkong untuk mendapatkan kualitas produk fermentasi dengan mutu terbaik.

\section{BAHAN DAN METODE}

Penelitian ini termasuk penelitian eksperimen dengan menggunakan Rancangan Acak Lengkap (RAL) pola faktorial yang terdiri atas dua faktor (Kusriningrum, 2012). Faktor pertama adalah konsentrasi ragi yaitu 0,5; 1 dan 1,5\%. Faktor kedua adalah lama fermentasi yaitu 1, 2 dan 3 hari. Kombinasi 2 faktor tersebut menghasilkan 9 kombinasi perlakuan. Setiap perlakuan diulang 3 kali sehingga diperoleh 27 unit percobaan. Rancangan percobaan kombinasi konsentrasi ragi dan lama fermentasi disajikan dalam Tabel 1. 
Tabel 1. Rancangan percobaan penelitian

\begin{tabular}{|c|c|c|c|}
\hline \multirow{2}{*}{$\begin{array}{c}\text { Konsentrasi } \\
\text { ragi }\end{array}$} & \multicolumn{3}{|c|}{ Lama fermentasi } \\
\hline & $\begin{array}{ll}1 & \text { hari } \\
\left(\mathrm{L}_{1}\right) & \end{array}$ & $\begin{array}{ll}2 & \text { hari } \\
\left(\mathrm{L}_{2}\right) & \end{array}$ & $\begin{array}{l}3 \\
\left(\mathrm{~L}_{3}\right)\end{array}$ \\
\hline $0,5 \%\left(\mathrm{~K}_{1}\right)$ & $\mathrm{K}_{1} \mathrm{~L}_{1}$ & $\mathrm{~K}_{1} \mathrm{~L}_{2}$ & $\overline{\mathrm{K}_{1} \mathrm{~L}_{3}}$ \\
\hline $1 \% \quad\left(\mathrm{~K}_{2}\right)$ & $\overline{\mathrm{K}_{2} \mathrm{~L}_{1}}$ & $\mathrm{~K}_{2} \mathrm{~L}_{2}$ & $\mathrm{~K}_{2} \mathrm{~L}_{3}$ \\
\hline $1,5 \%\left(\mathrm{~K}_{3}\right)$ & $\mathrm{K}_{3} \mathrm{~L}_{1}$ & $\overline{\mathrm{K}_{3} \mathrm{~L}_{2}}$ & $\mathrm{~K}_{3} \mathrm{~L}_{3}$ \\
\hline
\end{tabular}

Bahan yang digunakan untuk peremajaan ragi tape dan pembuatan tape singkong dapat dilihat pada Tabel 2.

harabel 2. Bahan yang digunakan untuk peremajaan

Variabel bebas dalam penelitian iniyaitu konsentrasi ragi dan lama fermentasi, sedangkan variabel terikatnya yaitu kadar air, kadar glukosa dan organoleptik. Sampel dalam penelitian ini adalah singkong spesies Manihot esculenta yang diambil dari populasi dengan menggunakan teknik purposive sampling. Tujuan dari penggunaan teknik ragi tape dan pembuatan tape singkong tersebut adalah jumlah sampel disesuaikan dengan

\begin{tabular}{|c||c|c|l|}
\hline N & Nama alat & No & Nama alat \\
\hline 1 & $\begin{array}{l}\text { Tepung ketan } \\
125 \mathrm{~g}\end{array}$ & 6 & Merica 4 g \\
\hline 2 & $\begin{array}{l}\text { Air perasan tebu } \\
220 \mathrm{ml}\end{array}$ & 7 & Cabe 4 g \\
\hline 3 & $\begin{array}{l}\text { Ragi yang telah } \\
\text { jadi 2 g }\end{array}$ & 8 & Daun pisang \\
\hline 4 & $\begin{array}{l}\text { Bawang putih 4 } \\
\mathrm{g}\end{array}$ & 9 & Daun sager \\
\hline 5 & Lengkuas 0,6 g & 10 & Singkong 900 g \\
\hline
\end{tabular}
kebutuhan yang digunakan dalam penelitian (Sudaryono, 2014). Jumlah sampel singkong dalam penelitian ini sebanyak $900 \mathrm{~g}$.

Prosedur kerja peremajaan ragi tape (Gandjar, 2003) dan pembuatan tape singkong (Hasanah et al, 2012) dijelaskan dalam Gambar 1 dan 2 di bawah ini.

Merica, cabe, lengkuas, bawang putih (digiling hingga halus lalu diayak)

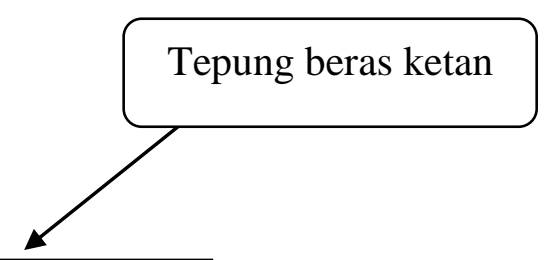

Bumbu dan tepung beras ketan dicampur dan ditambahkan air perasan tebu secukupnya hingga menjadi adonan

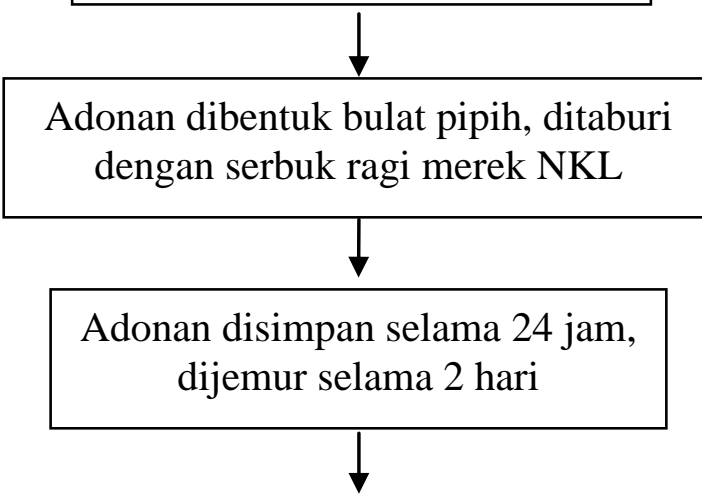

Adonan yang telah kering merupakan ragi yang siap untuk digunakan

Gambar 1. Bagan alir peremajaan ragi tape 


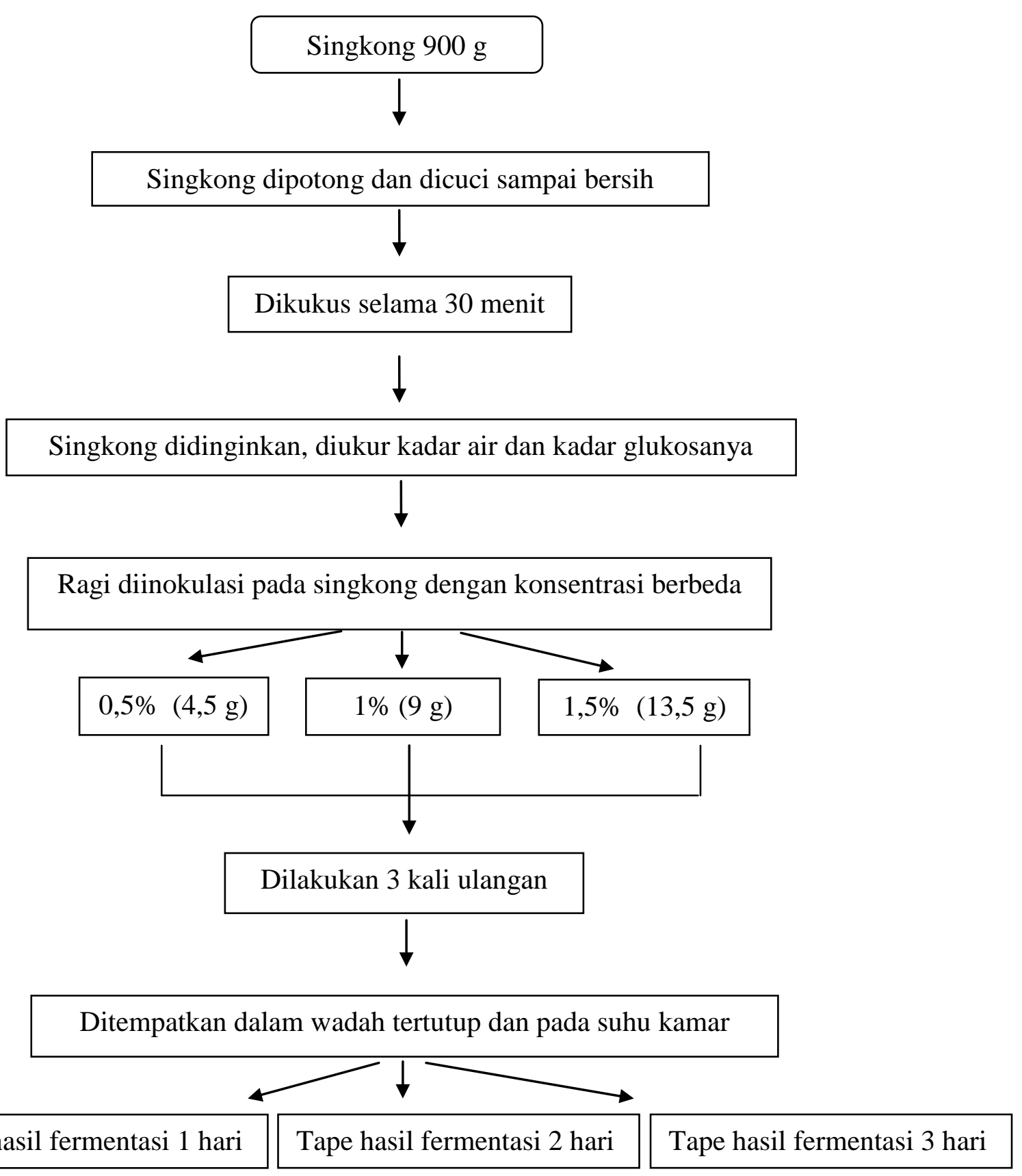

Tape hasil fermentasi 1 hari Tape hasil fermentasi 2 hari Tape hasil fermentasi 3 hari

Gambar 2. Bagan alir pembuatan tape singkong

III. HASIL DAN PEMBAHASAN

A. Hasil dan pembahasan kadar air pada sampel tape singkong

Data penelitian didapatkan dari hasil pengukuran kadar air pada sampel tape singkong berdasarkan konsentrasi ragi $(0,5 ; 1$ dan $1,5 \%)$ dan lama fermentasi $(1,2$, dan 3 hari). Metode yang digunakan adalah thermogravimetri (metode pemanasan) dengan hasil seperti yang terlihat pada Tabel 3 dan Gambar 3. 
Tabel 3. Rata-rata kadar air sampel tape singkong

\begin{tabular}{|c|c|c|c|c|}
\hline \multirow{2}{*}{$\begin{array}{c}\text { Jenis sampel } \\
\text { tape }\end{array}$} & Konsentrasi & \multicolumn{3}{|c|}{ Rata-rata kadar air pada lama fermentasi (hari) } \\
\cline { 3 - 5 } & ragi & 1 & 2 & 3 \\
\hline \multirow{3}{*}{ Singkong } & $0,5 \%$ & $58,47 \%$ & $55,28 \%$ & $56,81 \%$ \\
\cline { 2 - 5 } & $1 \%$ & $54,22 \%$ & $71,12 \%$ & $58,11 \%$ \\
\cline { 2 - 5 } & $1,5 \%$ & $56,33 \%$ & $63,15 \%$ & $58,95 \%$ \\
\hline
\end{tabular}

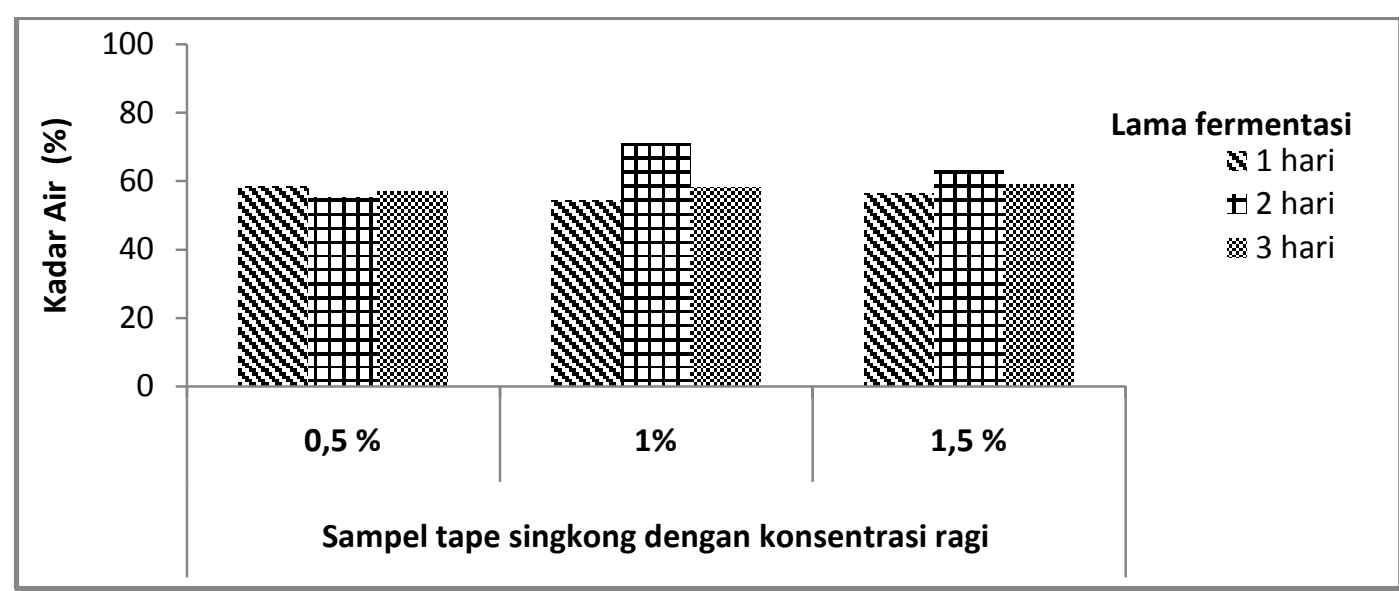

Gambar 3. Perbedaan kadar air pada sampel tape singkong berdasarkan konsentrasi ragi dan lama fermentasi

Berdasarkan data yang disajikan dalam tabel dan gambar di atas, dapat dilihat bahwa nilai kadar air dalam penelitian ini adalah dari $54,22 \%-71,12 \%$, dengan rata-rata kadar air terendah pada konsentrasi ragi $1 \%$ dan lama fermentasi 1 hari. Data kadar air tape singkong dari Badan Ketahanan Pangan Daerah Provinsi Jawa Barat (2014) dijadikan sebagai standar mutu produk tape singkong. Berdasarkan standar mutu tersebut, rata-rata kadar air tape singkong hasil penelitian termasuk dalam kategori bermutu tinggi karena kadar airnya lebih rendah dari $56,10 \%$.

Hasil uji hipotesis dengan anava dua jalur (Tabel 6) menunjukkan bahwa interaksi konsentrasi ragi dan lama fermentasi berpengaruh terhadap kadar air tape singkong ( $<<$ 0,05). Hasil uji lanjut (Tabel 7) menunjukkan bahwa rata-rata kadar air tape singkong konsentrasi ragi $1 \%$ dan lama fermentasi 1 hari berbeda secara signifikan dengan rata-rata kadar air pada konsentrasi ragi $1 \%$ dan lama fermentasi 2 hari dan konsentrasi ragi $1 \%$ dan lama fermentasi 3 hari. Menurut Sopandi dan Wardah (2014), mikroorganisme memanfaatkan beberapa komponen bahan dasar pangan sebagai substrat untuk menghasilkan energi dan komponen seluler, serta meningkatkan populasi. Hal ini dibuktikan dengan cukup tingginya kandungan karbohidrat dalam singkong sebesar 37,90 gram. Hasil penelitian yang menunjukkan adanya pengaruh konsentrasi ragi terhadap kadar air tape singkong, disebabkan oleh jumlah substrat yang diubah sangat tinggi, sehingga membutuhkan waktu yang cukup lama untuk proses metabolisme. Seperti yang dikemukakan oleh Poedjiadi dan Supriyanti (2005), kecepatan suatu reaksi yang menggunakan enzim akan meningkat jika konsentrasi enzim, konsentrasi substrat, suhu serta $\mathrm{pH}$ bertambah. Akan tetapi pada batas konsentrasi substrat serta suhu tertentu, tidak terjadi kenaikan kecepatan reaksi walaupun konsentrasi substrat serta suhu ditambahkan. Keadaan ini terjadi karena semua bagian aktif enzim telah dipenuhi oleh substrat. Apabila suhu terus mengalami kenaikan akan terjadi denaturasi, sehingga akan ada titik optimum bagi suatu reaksi yang menggunakan enzim tertentu. 


\section{B. Hasil dan pembahasan kadar glukosa pada} sampel tape singkong

Data penelitian didapatkan dari hasil pengukuran kadar glukosa yang terdapat pada sampel tape singkong berdasarkan konsentrasi ragi $(0,5 ; 1$ dan $1,5 \%)$ dan lama fermentasi (1, 2, dan 3 hari). Metode yang digunakan adalah uji gula reduksi dengan bantuan regresi linier dengan hasil seperti yang terlihat pada Tabel 4 dan Gambar 4.

Tabel 4. Hasil uji kadar glukosa sampel tape singkong

\begin{tabular}{|c|c|c|c|c|}
\hline \multirow{2}{*}{$\begin{array}{c}\text { Sampel } \\
\text { tape }\end{array}$} & $\begin{array}{c}\text { Konsentrasi } \\
\text { ragi }\end{array}$ & \multicolumn{3}{|c|}{ Rata-rata kadar glukosa pada lama fermentasi (hari) } \\
\cline { 3 - 5 } Singkong & $0,5 \%$ & $28,86 \%$ & 2 & 3 \\
\cline { 2 - 5 } & $1 \%$ & $27,94 \%$ & $51,25 \%$ & $41,14 \%$ \\
\cline { 2 - 5 } & $1,5 \%$ & $24,48 \%$ & $41,81 \%$ & $41,71 \%$ \\
\hline
\end{tabular}

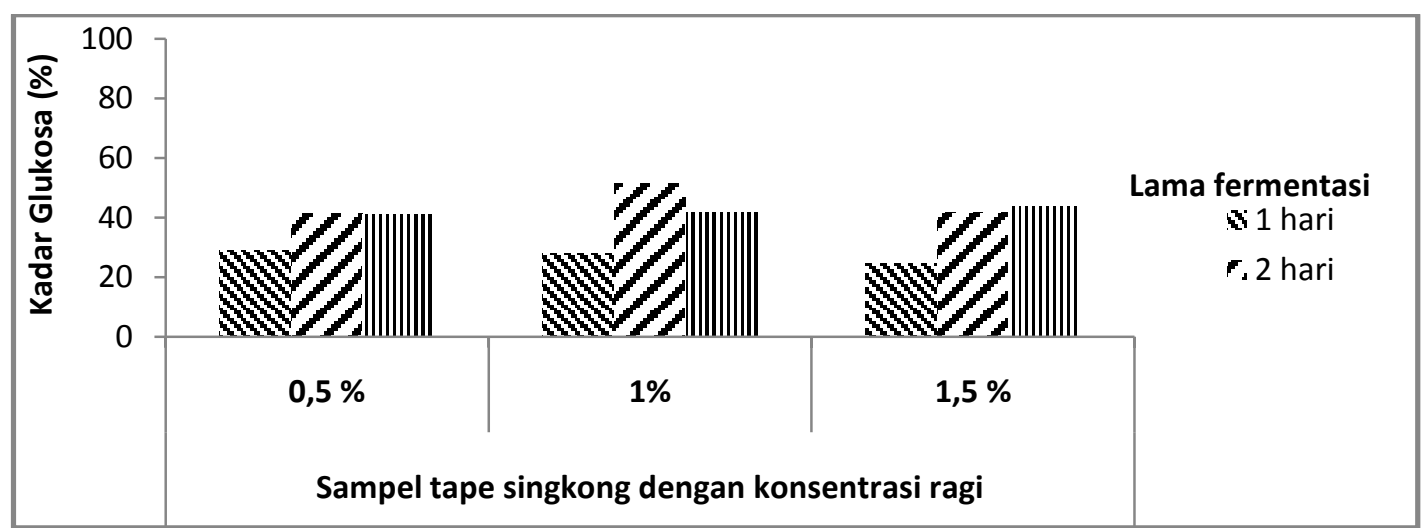

Gambar 4. Perbedaan kadar glukosa pada sampel tape singkong berdasarkan konsentrasi ragi dan lama fermentasi

Berdasarkan data yang disajikan dalam tabel dan gambar di atas, dapat dilihat bahwa nilai rata-rata kadar glukosa tertinggi dari kombinasi perlakuan konsentrasi ragi dan lama fermentasi terdapat pada sampel tape singkong dengan konsentrasi ragi $1 \%$ dan lama fermentasi 2 hari sebesar 51,61\%. Hasil uji hipotesis dengan anava dua jalur (Tabel 6) menunjukkan bahwa interaksi konsentrasi ragi dan lama fermentasi tidak berpengaruh terhadap kadar glukosa tape singkong $(p>0,05)$, dengan rata-rata kadar glukosa tape ketan dalam penelitian ini adalah dari $24,48 \%$ - 51,61\%, dengan rata-rata kadar glukosa tertinggi yaitu $51,61 \%$ pada konsentrasi ragi $1 \%$ dan lama fermentasi 2 hari. Data kadar glukosa tape singkong dari Badan Ketahanan Pangan Daerah Provinsi Jawa Barat (2014) dijadikan sebagai standar mutu produk tape singkong. Berdasarkan standar mutu tersebut, rata-rata kadar glukosa tape singkong hasil penelitian termasuk dalam kategori bermutu tinggi karena lebih besar dari 51,14\%.

Hasil penelitian yang menunjukkan tidak adanya pengaruh konsentrasi ragi dan lama fermentasi terhadap kadar glukosa tape singkong, disebabkan oleh jumlah substrat yang diubah cukup tinggi, sehingga membutuhkan waktu yang lama untuk proses metabolisme (Asngad dan Suparti, 2009). Hal tersebut sesuai dengan hasil uji lanjut (Tabel 7) yang 
menunjukkan tidak adanya perbedaan yang signifikan antara rata-rata kadar glukosa pada konsentrasi ragi $0,5 \%, 1 \%$ dan $1,5 \%$ pada lama fermentasi 1 hari serta rata-rata kadar glukosa pada konsentrasi ragi $0,5 \%, 1 \%$ dan $1,5 \%$ pada lama fermentasi 3 hari.

\section{Hasil dan pembahasan organoleptikpada} sampel tape singkong

Data penelitian didapatkan dari hasil pengukuran kualitas tape singkong yang diuji melalui tes organoleptik (uji warna, aroma, tekstur dan rasa) dinilai dengan 3 skala hedonik $($ tidak suka $=1$, suka $=2$, dan sangat suka $=3$ ) dengan mengambil rata-rata dari nilai warna, aroma, tekstur dan rasa. Adapun kriteria pengujian organoleptik menurut Wagiyono (2003), untuk uji warna (tidak berubah warna $=$ 1 , berubah warna $=2$, sangat berubah warna $=$ 3), kriteria untuk uji aroma (tidak beraroma tape $=1$, beraroma tape $=2$, sangat beraroma tape $=3$ ), kriteria untuk uji tekstur (keras $=1$, kenyal $=2$, sangat kenyal $=3$ ), kriteria untuk uji rasa (tidak manis $=1$, manis $=2$, sangat manis $=3$ ). Data penelitian hasil uji organoleptik seperti yang terlihat pada Tabel 5 dan Gambar 5.

Tabel 5. Hasil uji organoleptik pada sampel tape singkong berdasarkan konsentrasi ragi dan lama fermentasi

\begin{tabular}{|c|c|c|c|c|c|c|c|}
\hline \multirow{2}{*}{$\begin{array}{c}\text { Sampel } \\
\text { Tape }\end{array}$} & \multirow{2}{*}{$\begin{array}{c}\text { Konsentrasi } \\
\text { Ragi }\end{array}$} & \multirow{2}{*}{$\begin{array}{c}\text { Lama } \\
\text { Fermentasi }\end{array}$} & \multicolumn{4}{|c|}{ Rata-rata Organoleptik } & \multirow{2}{*}{ Rerata } \\
\hline & & & Warna & Aroma & Tekstur & Rasa & \\
\hline \multirow{9}{*}{ Singkong } & \multirow{3}{*}{$0.5 \%$} & 1 hari & 1.18 & 2.02 & 1.78 & 1.73 & 1.68 \\
\hline & & 2 hari & 1.27 & 1.93 & 2.02 & 1.75 & 1.74 \\
\hline & & 3 hari & 1.38 & 2.07 & 2.18 & 1.87 & 1.87 \\
\hline & \multirow{3}{*}{$1 \%$} & 1 hari & 1.20 & 2.07 & 1.85 & 1.95 & 1.76 \\
\hline & & 2 hari & 1.30 & 2.20 & 2.18 & 1.87 & 1.89 \\
\hline & & 3 hari & 1.30 & 2.33 & 2.33 & 2.18 & 2.04 \\
\hline & \multirow{3}{*}{$1.5 \%$} & 1 hari & 1.22 & 2.13 & 1.95 & 1.65 & 1.74 \\
\hline & & 2 hari & 1.33 & 2.35 & 2.18 & 2.07 & 1.98 \\
\hline & & 3 hari & 1.45 & 2.45 & 2.35 & 2.00 & 2.06 \\
\hline
\end{tabular}

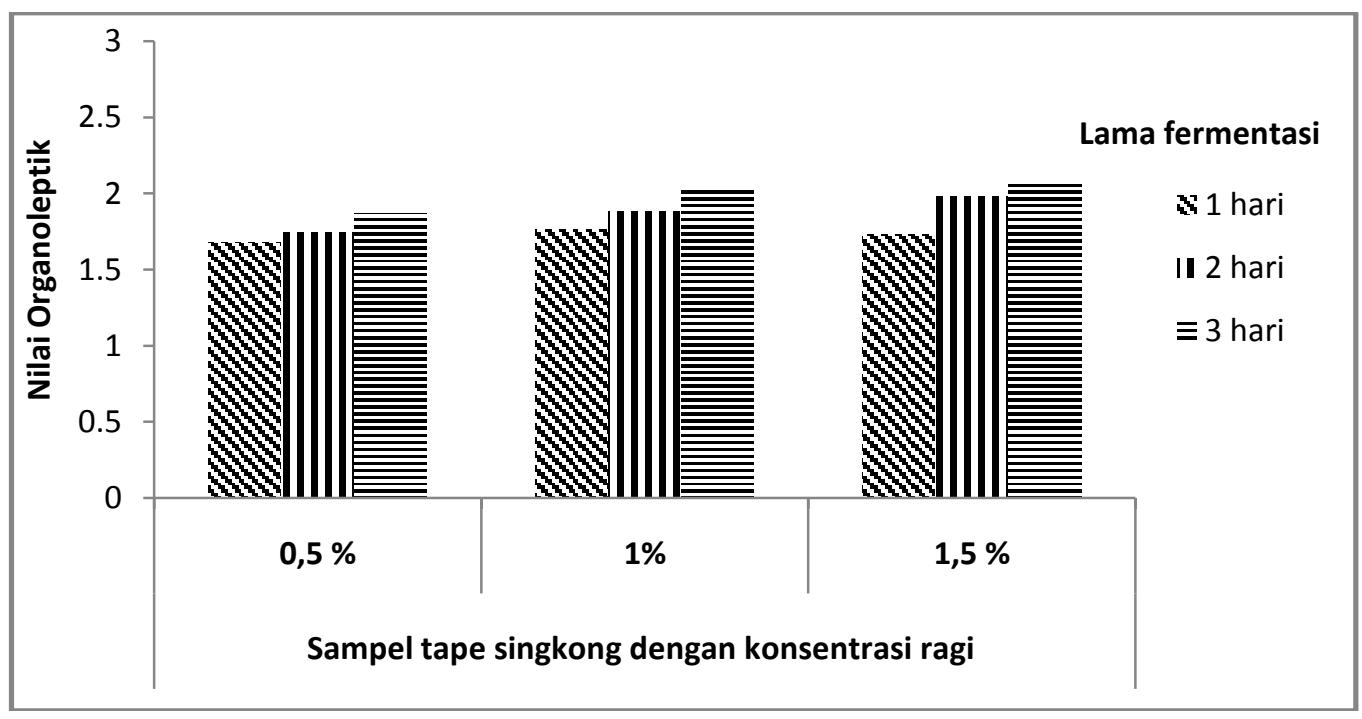


Gambar 5. Perbedaan organoleptik pada sampel tape singkong berdasarkan konsentrasi ragi dan lama fermentasi

Pada penelitian ini nilai warna, aroma dan tekstur tertinggi dengan nilai 1,$45 ; 2,45$ dan 2,35 pada konsentrasi ragi $1,5 \%$ dan lama fermentasi 3 hari yang berarti tidak berubah warna, beraroma tape dan teksturnya kenyal serta nilai rasa tertinggi sebesar 2,18 pada konsentrasi ragi $1 \%$ dan lama fermentasi 3 hari yang berarti berasa manis.

Berdasarkan data yang disajikan dalam tabel dan gambar di atas, dapat dilihat bahwa nilai ratarata organoleptik tertinggi dari kombinasi perlakuan konsentrasi ragi dan lama fermentasi terdapat pada sampel tape singkong dengan konsentrasi ragi 1,5\% dan lama fermentasi 3 hari sebesar 2,06 yang berarti tape disukai panelis. Hasil uji hipotesis dengan anava dua jalur (Tabel 6) menunjukkan bahwa interaksi konsentrasi ragi dan lama fermentasi tidak berpengaruh terhadap rata-rata organoleptik tape singkong $(p>0,05)$. Rata-rata organoleptik tape singkong dalam penelitian ini adalah 1,68 - 2,06 dengan rata-rata organoleptik tertinggi yaitu 2,06 pada konsentrasi ragi 1,5\% dan lama fermentasi 3 hari termasuk dalam kategori bermutu sedang karena rata-rata organoleptiknya lebih tinggi dari 2 yang berarti tape disukai panelis. Menurut Asngad dan Suparti (2009), tinggi rendahnya kadar glukosa dipengaruhi oleh tinggi rendahnya kandungan karbohidrat dalam bahan pangan. Kadar glukosa akan mempengaruhi rasa produk fermentasi yang dihasilkan. Hal ini sesuai dengan hasil uji lanjut (Tabel 7) menunjukkan tidak adanya perbedaan yang signifikan antara rata-rata organoleptik pada konsentrasi ragi $0,5 \%, 1 \%$ dan $1,5 \%$ dengan lama fermentasi 1 hari.

Data hasil penelitian mengenai kadar air, kadar glukosa dan organoleptik tape singkong dianalisis menggunakan analisis keragaman (ANAVA/Analisis of Variance) pada taraf kepercayaan 95\% seperti yang terlihat pada Tabel 6.

Tabel 6. Hasil uji Anava dua jalur pengaruh konsentrasi ragi terhadap kadar air pada sampel tape singkong

Tests of Between-Subjects Effects

\begin{tabular}{|l|l|r|r|r|r|l|}
\hline Source & Dependent Variable & $\begin{array}{l}\text { Type III Sum } \\
\text { of Squares }\end{array}$ & \multicolumn{1}{l|}{ df } & $\begin{array}{c}\text { Mean } \\
\text { Square }\end{array}$ & F & Sig. \\
\hline Singkong & & & & & \\
\hline \multirow{2}{*}{ konsentrasi_ragi } & Kadar Air & 59.487 & 2 & 29.744 & 7.227 & .005 \\
\cline { 2 - 7 } & Kadar Glukosa & 74.468 & 2 & 37.234 & .852 & .443 \\
\cline { 2 - 7 } & Organoleptik & .132 & 2 & .066 & 9.737 & .001 \\
\hline \multirow{2}{*}{ lama_fermentasi } & Kadar Air & 281.028 & 2 & 140.514 & 34.143 & .000 \\
\cline { 2 - 7 } & Kadar Glukosa & 1660.194 & 2 & 830.097 & 18.986 & .000 \\
\cline { 2 - 7 } & Organoleptik & .316 & 2 & .158 & 23.255 & .000 \\
\hline konsentrasi_ragi * & Kadar Air & 264.376 & 4 & 66.094 & 16.060 & .000 \\
\cline { 2 - 7 } & Kadar Glukosa & 174.496 & 4 & 43.624 & .998 & .434 \\
\cline { 2 - 7 } & Organoleptik & .027 & 4 & .007 & .995 & .435 \\
\hline
\end{tabular}

Keterangan: jika $\mathrm{p} \leq 0.05$ maka Ha diterima (berpengaruh)

Data hasil penelitian menunjukkan adanya pengaruh yang signifikan, maka data selanjutnya dianalisis menggunakan Uji Beda Nyata Terkecil (BNT) pada taraf kepercayaan 95\% seperti yang terlihat pada Tabel 7. 
Tabel 7. Hasil uji BNT rata-rata kadar air, kadar glukosa dan organoleptik pada sampel tape singkong

\begin{tabular}{|c|c|c|c|c|c|}
\hline $\begin{array}{c}\text { Sampel } \\
\text { tape }\end{array}$ & $\begin{array}{c}\text { Konsentrasi } \\
\text { ragi }\end{array}$ & $\begin{array}{c}\text { Lama } \\
\text { fermentasi }\end{array}$ & $\begin{array}{c}\text { Kadar } \\
\text { air }\end{array}$ & $\begin{array}{c}\text { Kadar } \\
\text { glukosa }\end{array}$ & Organoleptik \\
\hline \multirow{4}{*}{$0,5 \%$} & 1 hari & $58.47^{\mathrm{c}}$ & $28.86^{\mathrm{a}}$ & $1.68^{\mathrm{a}}$ \\
\cline { 3 - 6 } & \multirow{3}{*}{ Singkong } & 2 hari & $55.28^{\mathrm{a}}$ & $41.24^{\mathrm{b}}$ & $1.74^{\mathrm{a}}$ \\
\cline { 3 - 6 } & \multirow{3}{*}{$1 \%$} & 3 hari & $56.81^{\mathrm{a}}$ & $41.13^{\mathrm{b}}$ & $1.87^{\mathrm{b}}$ \\
\cline { 3 - 6 } & & 1 hari & $54.22^{\mathrm{a}}$ & $27.94^{\mathrm{a}}$ & $1.76^{\mathrm{a}}$ \\
\cline { 3 - 6 } & \multirow{3}{*}{$1,5 \%$} & 2 hari & $71.12^{\mathrm{e}}$ & $51.61^{\mathrm{c}}$ & $1.88^{\mathrm{b}}$ \\
\cline { 3 - 6 } & & 3 hari & $58.11^{\mathrm{b}}$ & $41.71^{\mathrm{b}}$ & $2.03^{\mathrm{d}}$ \\
\cline { 3 - 6 } & & 1 hari & $56.33^{\mathrm{a}}$ & $24.47^{\mathrm{a}}$ & $1.73^{\mathrm{a}}$ \\
\cline { 3 - 6 } & & 2 hari & $63.15^{\mathrm{d}}$ & $41.81^{\mathrm{b}}$ & $1.98^{\mathrm{c}}$ \\
\cline { 3 - 6 } & & 3 hari & $58.95^{\mathrm{c}}$ & $43.91^{\mathrm{b}}$ & $2.06^{\mathrm{d}}$ \\
\hline
\end{tabular}

Keterangan: angka yang memiliki notasi huruf yang sama tidak berbeda nyata secara signifikan

\section{KESIMPULAN}

Berdasarkan hasil analisis data dan pembahasan, maka dapat ditarik kesimpulan sebagai berikut:

1. Konsentrasi ragi berpengaruh terhadap kadar air dan organoleptik tetapi tidak berpengaruh pada kadar glukosa tape singkong.

2. Lama fermentasi berpengaruh terhadap kadar air, glukosa dan organoleptik tape singkong.

3. Interaksi antara konsentrasi ragi dan lama fermentasi berpengaruh terhadap kadar air tetapi tidak berpengaruh terhadap kadar glukosa dan organoleptik tape singkong.

\section{DAFTAR PUSTAKA}

Asngad, A dan Suparti. 2009. Lama Fermentasi dan Dosis Ragi yang Berbeda pada Fermentasi Gaplek Ketela Pohon (Manihot utilissima, Phol) Varietas Mukibat terhadap Kadar Glukosa dan Bioetanol. Jurnal Penelitian Sains \& Teknologi. 10(1): 1-9.

Badan Ketahanan Pangan Daerah Provinsi Jawa Barat. 2014. Manfaat Tape (peuyeum). http://bkpd.jabarprov.go.id/manfaat-tapepeuyeum. Diakses pada tanggal 17 November 2016.

Badan Ketahanan Pangan Kementrian Pertanian RI. 2012. Roadmap Diversifikasi Pangan Tahun 2011-2015 Edisi 2. Badan Ketahanan Pangan Kementrian Pertanian RI.

Badan Pusat Statistik Provinsi NTB. 2016. Produksi Singkong (Ton) di Seluruh NTB. www.bps.go.id, diakses pada tanggal 6 Agustus 2016.

Departemen Pertanian. 2012. Pengembangan usaha tepung tapioka. Jakarta.

FAOSTAT. 2015. Survey Ekkonomi OECD Indonesia. http://faostat3.fao.org Diakses pada tanggal 10 Februari 2016.

Hasanah, A. M. 2007. Pengaruh total mikroba pada merk ragi dan lama fermentasi terhadap kadar alkohol tape ketan putih (Oryza sativa l. Var. Forma glutinosa). Fakultas Sains dan Teknologi, Universitas Islam Negeri Malang.

Hasanah, H., Jannah, A dan Fasya, A. G. 2012. Pengaruh Lama Fermentasi Terhadap Kadar Alkohol Tape Singkong (Manihot utilissima Pohl) ALCHEMY. 2(1):1-100.

Hidayati, D., Ba'ido, D., dan Hastuti, S. 2013. Pola Pertumbuhan Ragi Tape pada Fermentasi Kulit Singkong. Agrointek. 7(1).

Kusriningrum, R. S. 2012. Perancangan Percobaan. Surabaya: Airlangga University Press.

Poedjiadi, A dan Supriyanti, F. M. T. 2005. DasarDasarBiokimia edisi revisi. Jakarta: Universitas Indonesia-Press.

Santosa, A dan Prakosa, C. 2010. Karakteristik Tape Buah Sukun Hasil Fermentasi Penggunaan Konsentrasi Ragi Yang Berbeda. Magistra. 73.

Simbolon, K. 2008. Pengaruh persentase ragi tape dan lama fermentasi terhadap mutu tape ubi jalar. USU Repository.

Sopandi, T dan Wardah. 2014. Mikrobiologi Pangan (Teori dan Praktik). Yogyakarta: Andi Offset. 
Sudaryono. 2014. Teori dan Aplikasi dalam

Statistik. Yogyakarta: Andi Offset.

Survei Sosial Ekonomi Nasional 2009-2013. 2013.

Konsumsi Rata-Rata perKapita Setahun

Beberapa Bahan Makanan di Indonesia, 2009-2013. Survei Sosial Ekonomi

Nasional.

Wagiyono. 2003. Menguji kesukaan secara organoleptik. Bagian Proyek Pengembangan Kurikulum. Departemen Pendidikan Nasional. 